\title{
Strontium $\left({ }^{87} \mathbf{S r} /{ }^{86} \mathbf{S r}\right)$ dating of marine shells from Pliocene and Pleis- tocene shallow marine deposits in The Netherlands
}

\author{
H.S.M. Jansen ${ }^{1}$, J. Huizer ${ }^{2}$, J.W.A. Dijkmans ${ }^{3} \&$ J.E. van Hinte ${ }^{4}$ \\ ${ }^{1} \mathrm{~J} \& \mathrm{G}$ Consultants, J.Rosenkrantzlaan 35, 2104 CC Heemstede \\ ${ }^{2}$ TNO-NITG \& Faculty of Earth and Life Sciences, Vrije Universiteit, De Boele- \\ laan 1085, $1081 \mathrm{HV}$ Amsterdam, The Netherlands \\ ${ }^{3}$ TNO-NITG, Postbus 80015, 3508 TA Utrecht, The Netherlands \\ ${ }^{4}$ de Lairessestraat 78 lh, $1071 \mathrm{PH}$ Amsterdam, The Netherlands
}

Manuscript received: October 2002, Accepted: September 2003

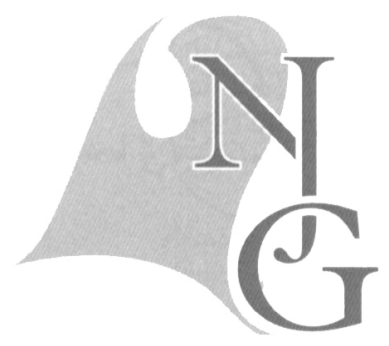

\begin{abstract}
${ }^{87} \mathrm{Sr}{ }^{86} \mathrm{Sr}$ (Strontium) ratio analyses of shell material (mainly Arctica islandica) from 24 levels in the Maassluis Formation of boreholes Noordwijk, Zegveld and Terschelling suggest that the age of the formation ranges from 0.82 to $2.34 \mathrm{Ma}( \pm 0.5$ $\mathrm{Ma}$ ), and that the Oosterhout Formation at Noordwijk could be as much as $2.5 \mathrm{Ma}$ older than hitherto assumed.

Keywords: Maassluis Formation, Oosterhout Formation, Strontium isotopes
\end{abstract}

\section{Introduction}

The TNO-NITG funded 'Process model Lower Pleistocene' project aims to decipher the subsurface stratal patterns of the shallow marine and deltaic Maassluis Formation in order to reconstruct the Late Pliocene and Early Pleistocene depositional history of the Netherlands. A coherent lithological facies model of the Lower Pleistocene marine deposits in The Netherlands is lacking. However, such a model is of great importance both to the geological mapping of The Netherlands and the understanding of the geohydrological properties of these deposits that form the base of the shallow groundwater system.

The Maassluis Formation was deposited at the southern margin of the North Sea Basin, with the coastline shifting rapidly in response to climatic events (Laban, 1995). Figs 1 and 2 show the depositional limits, directions of main sediment supply and lithostratigraphic position of the Maassluis Formation. By definition (Doppert et al., 1975), its top is marked by the top occurrence of marine shells and its base is marked by the top occurrence of glauconite. Several biostratigraphical studies of this interval are available, mainly on foraminifera and molluscs (see Zagwijn \& Van Staalduinen, 1975, for a summary). The foraminiferal content of the Maassluis Formation generally fits in the FAl biozone and partly in the FA2 biozone of Doppert (1975), which correlate with the Early Pleistocene and the Late Pliocene sensu Zagwijn $(1975,1998)$ respectively. The Maassluis Formation pollen content is generally of Tiglian nature, its top is usually in the TC4c pollen zone (Van Montfrans, 1975) but can be as high as TC5 in the Brielle area (Gibbard et al., 1991). These pollen zones are generally used to indicate the age of this formation, even in cases where the palynological analysis was on dinoflagellates using British dinoflagellate events (Van Kolfschoten \& De Boer, 1988). Up to now, only numeric ages derived from magnetostratigraphy were available for these sediments (Van Montfrans, 1971).

To obtain additional numeric age estimates, the ${ }^{87} \mathrm{Sr} /{ }^{86} \mathrm{Sr}$ ratio of shell material from the Maassluis 


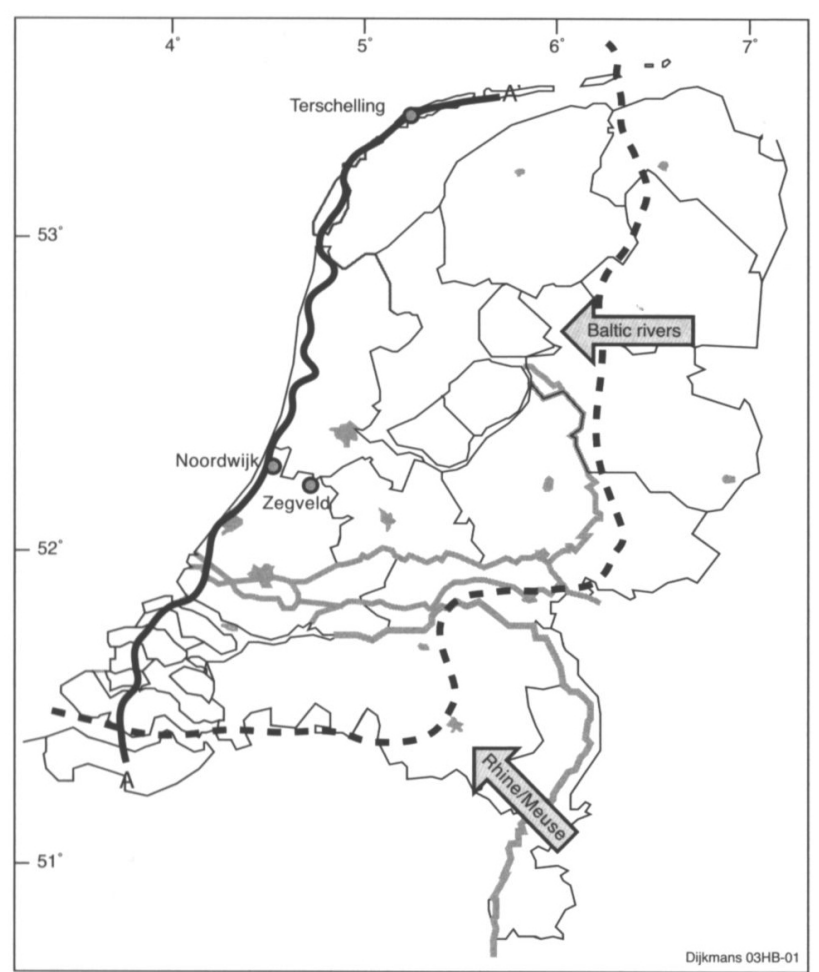

Fig. 1. Map of The Netherlands with location of boreholes used in this paper, southern and eastern boundary of Maassluis Formation occurrence (dashed line, from Zagwijn, 1975) and directions of river sediment transport during Praetiglian and Tiglian. Line A-A' marks location of profile in Fig. 2.
Formation was determined. to improve on positioning the Maassluis Formation in the numeric time scale, to date the litho- and biostratigraphic units of the boreholes used in this paper, and to test the timestratigraphic value of traditional correlation.

For consistency with Beets' (1992, Chapter 2) earlier study on dutch material, the shell material has been dated using his calculation method on the ${ }^{87} \mathrm{Sr} /{ }^{86} \mathrm{Sr}$ ratios. This provides age estimates with a 0.5 $\mathrm{Ma}$ uncertainty for the $0.0-2.34 \mathrm{Ma}$ age interval. The numeric ages refer to the timescale of Berggren et al. (1985), as used by Beets (1992). More modern compilations of Sr-isotope stratigraphy data (Howarth \& McArthur, 1997; McArthur et al., 2001) are usually based on the timescale of Shackleton et al. (1995) for the 0 - 6.4 Ma interval.

Application of strontium isotope chronostratigraphy to shallow marine deposits, such as beach to upper shelf, can be hampered by being positioned too far away from the world oceanic circulation of water masses, or by a dominant input of river source with deviating Strontium signature. The North Sea Basin had an open connection to the Atlantic Ocean during the Pliocene and Early Pleistocene, so restriction from world oceanic water masses should not be a problem in this area. The river Rhine precursor (in-

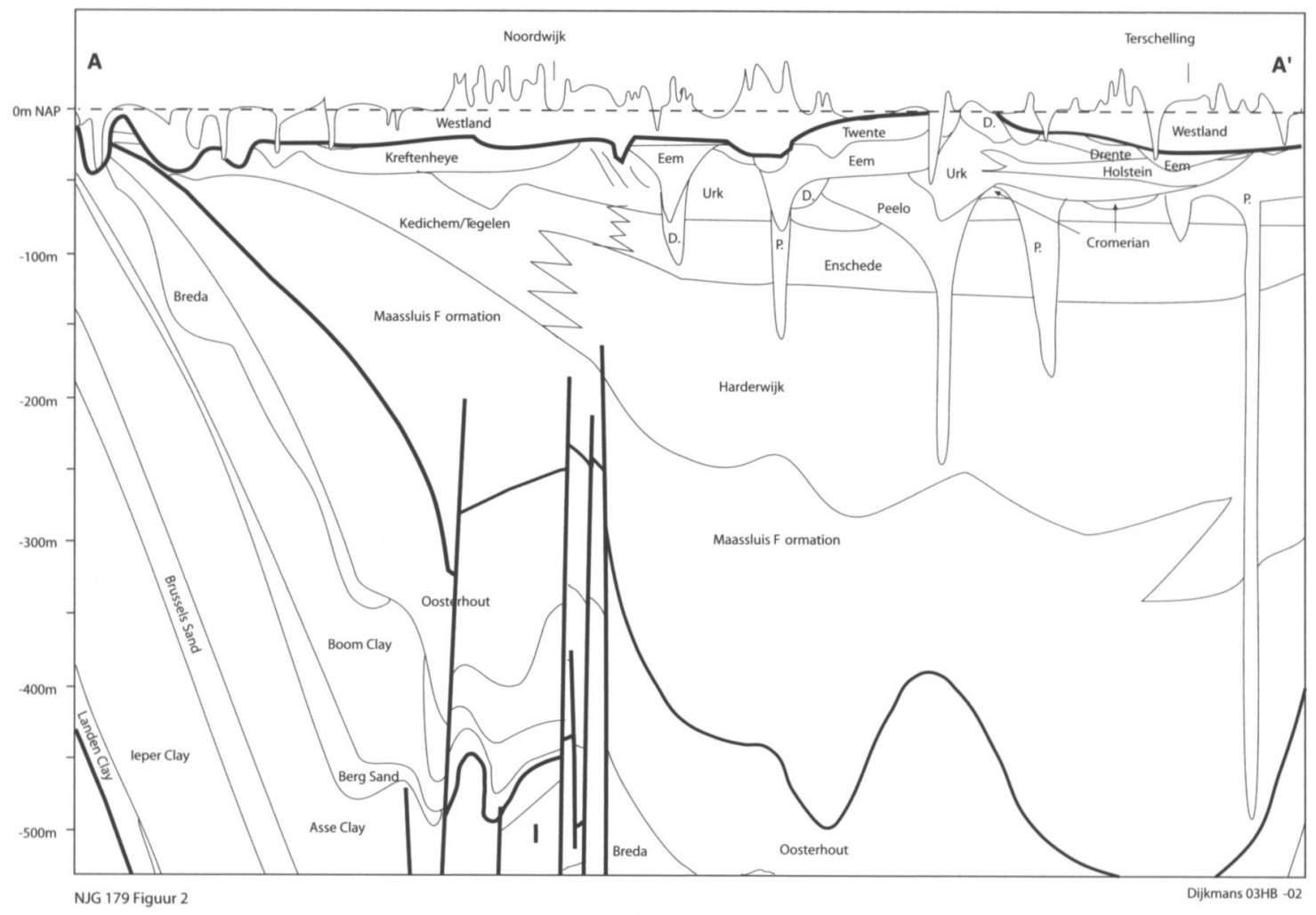

Fig. 2. Schematic profile showing the relation of the Maassluis Formation with other formations in the Dutch subsurface. After a profile compiled by De Gans, Parker-Witmans \& Zwaan (TNO-NITG) for a 1995 exhibition to commemorate the 750 year existence of the city of Haarlem (lithostratigraphy cf. Zagwijn \& Van Staalduinen, 1975). The location is indicated on Fig. 1. NAP = Normaal Amsterdams Peil. Note the fault block position of the Noordwijk borehole. 
cluding Meuse), which flowed to the West through northern Belgium (Kasse, 1988), and of the Baltic river system from the East-northeast, however, may have been of influence on the isotopic ratios in their delta areas.

\section{Materials and methods}

For this study 23 samples were analysed, 10 from borehole Noordwijk (RD Coordinates X: 91520, Y: 471800), 8 from hole Zegveld (X: 115382, Y:460157) and 6 from hole Terschelling (X:143820, Y:598430), see Fig. 1 and Table 1. The position of the Maassluis Formation in the boreholes was established using TNO-NITG's sediment-petrological (Burger, 1998) and geological interpretations of airlifted samples. In hole Noordwijk, where the location of the base of the Maassluis Formation was uncertain at the time of sampling, the interval of uncertainty was also sampled.

From the airlifted samples of shell bearing sands and clays, the 24 shell samples were picked, mostly of the bivalve Arctica islandica. The specimens were selected after visual inspection for their pristine appearance by NITG malacologists T.Meijer (Noordwijk) and R.Pouwer (Zegveld and Terschelling), to avoid measurements on specimens that are either reworked or show alteration of their shell material. No SEM photography, cathode-luminescence or trace element analysis to further assess the diagenetic state of the studied material was done.

The shells were cleaned, pulverised, dissolved in $5 \mathrm{~N}$ acetic acid (HOAc) and centrifuged, after which the Strontium-bearing "supernatant" could be siphoned off with a pipette. The Strontium was separated in a set of chromatography columns, filled with the Strontium retaining resin "Sr-spec". The resulting samples were dried down on a hot plate. The Strontium preparations were loaded onto outgassed zonerefined Rhenium filaments. For each ca. 10 samples a Standard Reference Material NBS 987 standard as well as a modern seawater standard was loaded, to control the quality of the measurements.

The filaments were measured in a thermal ionisation solid source mass-spectrometer (either Finnigan MAT 261 or 262). The data were corrected for $\mathrm{Rb}$ interference and normalized to a ${ }^{86} \mathrm{Sr} /{ }^{88} \mathrm{Sr}$ ratio of 0.1194 and a NBS 987 standard value of 0.710255 (see Vonhof, 1998, p. 19, for an ample discussion of these methods).

On the Noordwijk hole $\delta^{18} \mathrm{O}$ and $\delta^{13} \mathrm{C}$ isotopic analyses were done on the same shells as those used for the Strontium measurements. These measurements can provide information about the depositional environment of the assemblages.
Table 1. Strontium isotope ratio measurements on 24 samples from three boreholes in The Netherlands. ${ }^{87} \mathrm{Sr} /{ }^{86} \mathrm{Sr}$ values are corrected to a NBS 987 standard value of 0.710257 or to a coral standard value of 0.709178 . SE is Standard Error.

\begin{tabular}{|c|c|c|c|}
\hline $\begin{array}{l}\text { Hole Depth } \\
\text { (m) }\end{array}$ & ${ }^{87} \mathrm{Sr} /{ }^{86} \mathrm{Sr}$ & $2 \times S E$ & Species \\
\hline \multicolumn{4}{|l|}{ Noordwijk } \\
\hline 132.75 & 0.709081 & 11 & Arctica islandica \\
\hline 133.75 & 0.709087 & 11 & Arctica islandica \\
\hline 157.25 & 0.709059 & 9 & Arctica islandica \\
\hline 179.25 & 0.709050 & 7 & Arctica islandica \\
\hline 200.25 & 0.709053 & 8 & Macoma praetenuis \\
\hline 218.25 & 0.709045 & 6 & Arctica islandica \\
\hline 239.25 & 0.709079 & 13 & Arctica islandica \\
\hline 255.25 & 0.709010 & 8 & indet. \\
\hline 275.25 & 0.709035 & 10 & Arctica islandica \\
\hline 304.60 & 0.709005 & 10 & Arctica islandica \\
\hline \multicolumn{4}{|l|}{ Zegveld } \\
\hline 165.50 & 0.709099 & 8 & Arctica islandica \\
\hline 205.50 & 0.709086 & 6 & Arctica islandica \\
\hline 220.50 & 0.709092 & 9 & Arctica islandica \\
\hline 226.50 & 0.709084 & 6 & Arctica islandica \\
\hline 256.50 & 0.709088 & 9 & Arctica islandica \\
\hline 266.50 & 0.709190 & 11 & Arctica islandica \\
\hline 271.50 & 0.709092 & 11 & Arctica islandica \\
\hline 285.50 & 0.709123 & 10 & Arctica islandica \\
\hline \multicolumn{4}{|l|}{ Terschelling } \\
\hline 282.20 & 0.709176 & 7 & Arctica islandica \\
\hline 318.70 & 0.709174 & 7 & Arctica islandica \\
\hline 353.20 & 0.709221 & 5 & Arctica islandica \\
\hline 383.70 & 0.709132 & 9 & Arctica islandica \\
\hline 403.70 & 0.709146 & 8 & Arctica islandica \\
\hline 427.30 & 0.709128 & 6 & Arctica islandica \\
\hline
\end{tabular}

\section{Results}

Figs 3-6 show the measured intervals of the three boreholes. Some of the ages calculated for the samples fall within the Strontium isotopic ratio 'platform' as defined by Beets (1992), Farrel et al. (1995) and others, which is a region in the Strontium isotope curve where the ${ }^{87} \mathrm{Sr} /{ }^{86} \mathrm{Sr}$ ratio is more or less constant. Beets (1992) defines this platform between ratios 0.709080 and 0.709050 , which covers the period from 2.34 Ma to $4.43 \mathrm{Ma}$. These measurements are therefore considered less reliable for age dating, although they may still be used to provide a minimum age for the sample.

Fig. $3\left({ }^{87} \mathrm{Sr} /{ }^{86} \mathrm{Sr}\right.$ ratio measurements plotted against depth) shows that a linear trend in the measurements is only clearly present in Noordwijk, where Terschelling has a two-step trend. We ignored values that either obviously deviated from the trend or are outside the seawater range. For values within the ratio 


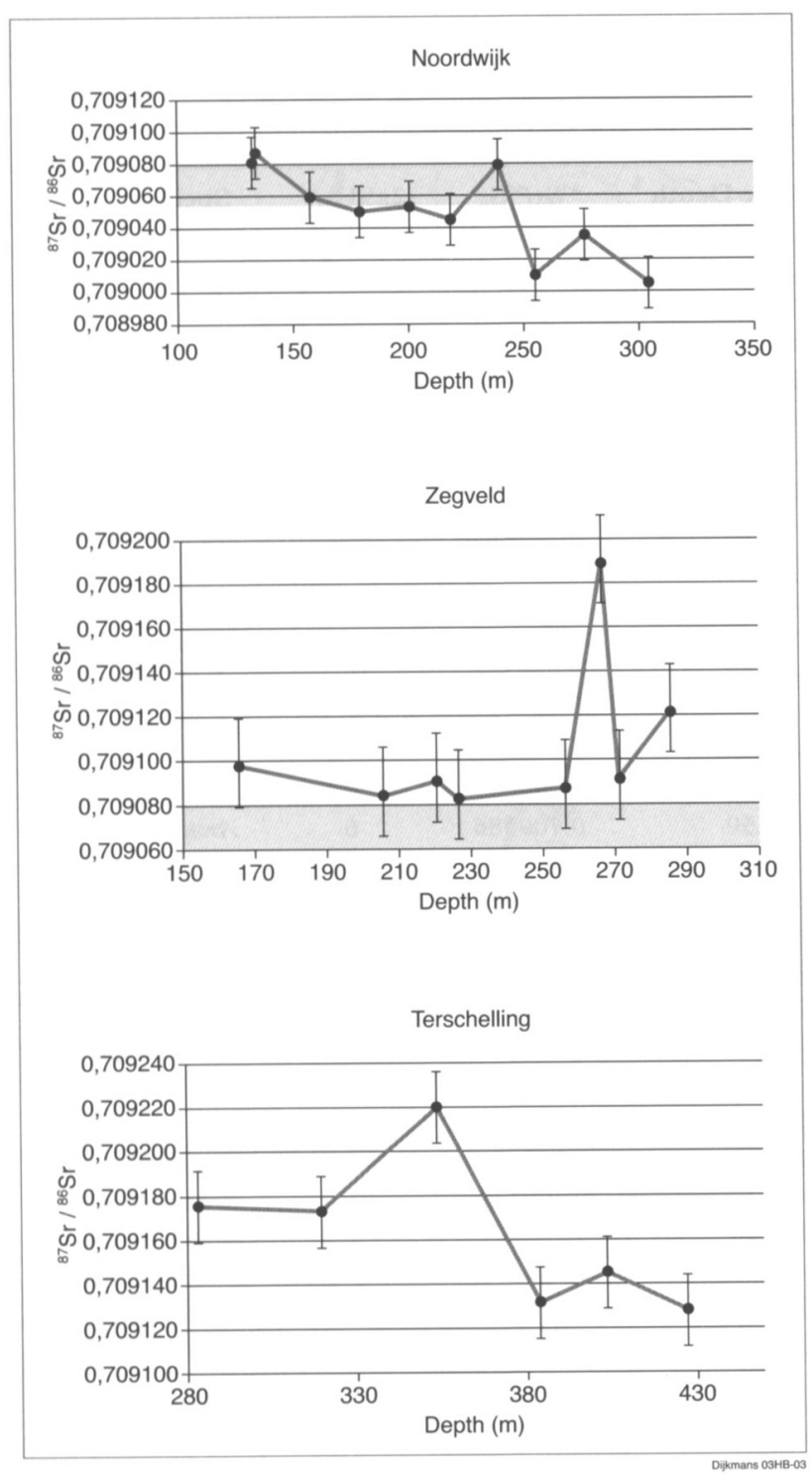

Fig. $3 .{ }^{87} \mathrm{Sr} /{ }^{86} \mathrm{Sr}$ ratios versus depth of the three holes. The grey area represents Strontium ratio "platform" values (see text). Note lack of downward trend in Zegveld and two-step trend in Terschelling. Also note differences in vertical scale.

platform the minimum value can be used.

\section{Noordwijk}

In borehole Noordwijk (Fig. 4) the lithostratigraphy left some doubt about the position of the base of the Maassluis Formation (Burger, 1998), so the sampling interval included the zone of uncertainty (222-283 $\mathrm{m})$. Currently, NITG places the base at $239.75 \mathrm{~m}$, based on the first downhole occurrence of glauconite in the sediment.

As shown in Fig. 3 and Fig. 4, the Strontium isotope ratios decrease gradually, if irregularly, downwards. The calculated Strontium ages at the top of the formation are around 2.0 Ma. Near the base of the
Maassluis Formation $(239.25 \mathrm{~m})$ the estimated Srisotope age is in the 2.34 to $4.43 \mathrm{Ma}$ 'platform' age range, which gives a minimum age of $2.34 \mathrm{Ma}( \pm 0.5$ $\mathrm{Ma}$ ). However, at $218.25 \mathrm{~m}$ the $\mathrm{Sr}$-isotope ratios suggest an age of $4.7 \mathrm{Ma}$, which would extend the age range of the Maassluis Formation well into the Early Pliocene.

Below this, in the Oosterhout Formation, the Strontium isotope ratio values suggest ages in the 4.8 -5.2 Ma (Early Pliocene) range. Since these are in line with that at the base of the Maassluis Formation as currently defined in this hole, the $\mathrm{Sr}$-isotope ratios of these sediments actually suggest that the base of the Maassluis Formation should be placed higher, around $200 \mathrm{~m}$ rather than at $239.75 \mathrm{~m}$, possibly with a hiatus between the Maassluis and Oosterhout formations spanning about $2.2 \mathrm{Ma}$. There is a clear log break around $202 \mathrm{~m}$, which separates a blocky (sand) $\log$ pattern above from three sand-clay gradations (Fig. 4) below.

Below $202 \mathrm{~m}$, the isotope ages are at odds with the dinoflagellate (Munsterman, 1999), foraminiferal (Van Leeuwen, 1999) and mollusc (Meijer, oral communication) stratigraphy of this borehole. These suggest a Praetiglian to Tiglian- $A$ position for the sediments from $307.10 \mathrm{~m}$ to $251.75 \mathrm{~m}$ ( 2 to $2.5 \mathrm{Ma}$ ), and Tiglian-B and $-\mathrm{C}$ (1.6 to $2 \mathrm{Ma}$ ) for the sediments from $244.75 \mathrm{~m}$ to $131.25 \mathrm{~m}$ (Fig. 4).

Munsterman (1999) mentions that the sediments from $307 \mathrm{~m}$ to $210 \mathrm{~m}$ were deposited under neritic conditions (outer neritic between 251-257 m) and arctic influence (peaking at 258-259 m), with both arctic and oceanic influences decreasing between 245 $\mathrm{m}$ and $210 \mathrm{~m}$. This is in line with the $\delta^{18} \mathrm{O}$ isotopic data that suggest cold-water conditions in this interval (Fig. 4). As there has been arctic water (North Atlantic Deep Water) since the Late Miocene (Kennett, 1982, p. 737), finding a 'cold' signal in open and deep marine deposits on the northern hemisphere therefore does not automatically imply that the sediments are of Praetiglian (or younger) age. Only if established chrono-species ranges are used one can be confident about the biostratigraphic age estimate. The Strontium ratios in the Oosterhout/Maassluis formations of more locations will have to be measured to establish if there is a systematic difference between the age estimates of biostratigraphy and Strontium isotopes in these sediments. The data from our study indicates that this only occurs in the Noordwijk area.

River input influence on Strontium isotope ratios in these sediments is a possible alternative cause for these deviating values. Indeed, Kasse (1988) describes how the Rhine/Meuse River deposits are the lateral equivalent of the marine Oosterhout deposits 


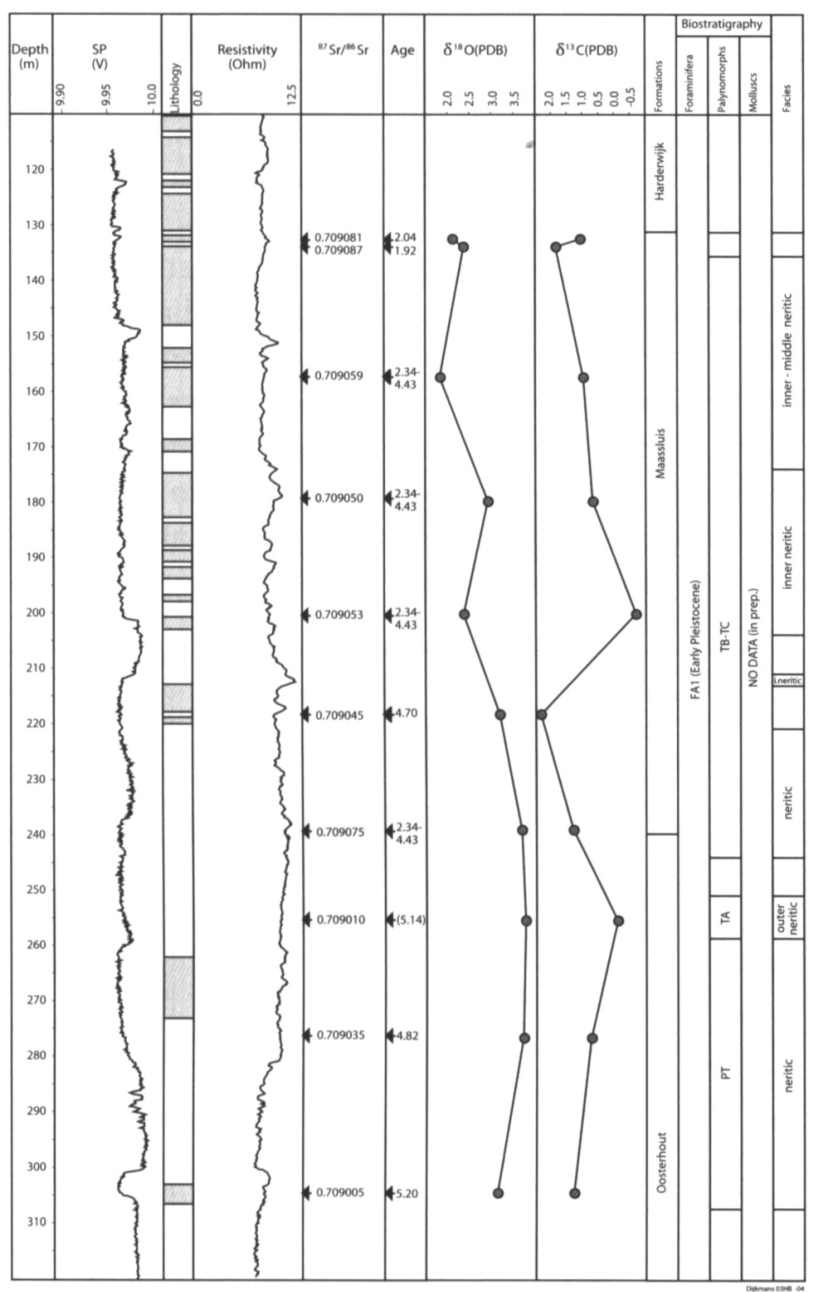

Fig. 4. Summary of the Noordwijk borehole data. Age estimates based on Strontium measurements calculated after Beets (1992). The schematic lithology is a summary of the detailed lithological description compiled by NITG: White intervals denote sandy and silty clay, grey intervals indicate sand.

during the Pliocene and Praetiglian without any substantial tidal deposits, characteristic of the rest of the Tiglian, between them. Burger (1998) mentions river influences in the interval from $213.75 \mathrm{~m}$ to $224.75 \mathrm{~m}$, based on an increased proportion of 'coarse-stable' minerals. Thus river discharge might have directly influenced the marine realm, by providing Strontium to the system. However, the average modern rivers provide "high ${ }^{87} \mathrm{Sr} /{ }^{86} \mathrm{Sr}$ ratio" Strontium (Beets, 1992). Since the Plio-/Pleistocene Rhine/Meuse had the same hinterland as the present system, we would expect this to lead to lower ('younger') age estimates for these sediments rather than the old ages we found. We would also expect a river discharge effect to be widespread, but actually it does not affect the nearby Zegveld location.

Diagenetic effects may have influenced our measurements through the upward movement of forma- tion water, carrying 'low ${ }^{87} \mathrm{Sr} /{ }^{86} \mathrm{Sr}$ ratio' Strontium to higher strata. This can lead to diagenetic alteration of the shell material in these higher strata to lower Srisotope ratios and consequently to age estimates which are too high. Since this effect is not recorded in the nearby Zegveld hole, it must be a local phenomenon, possibly related to fluid migration along a fault line.

\section{Zegveld}

In Zegveld (Fig. 5), the age range for the Maassluis Formation suggested by the Sr-isotope ratios runs from about $1.70 \mathrm{Ma}$ at the top to $1.90 \mathrm{Ma}$ near the base, on average slightly younger than the Maassluis Formation in Noordwijk (2.0 to $2.34 / 4.43 \mathrm{Ma}$ ). The expected downward trend in the isotope ratio data is not very apparent (Fig. 3) and rather seems to hover around an average of $0.709090(1.86 \mathrm{Ma})$. This suggests that these sediments have been deposited fairly rapidly in a short period of time, more rapidly than in the nearby Noordwijk hole.

The sampled interval lies in the FAl foraminiferal zone (Van Leeuwen, 2000), which does not contradict the Strontium isotope ages. No palynological or mollusc data is available for this hole yet.

\section{Terschelling}

In Terschelling (Fig. 3 and Fig. 6) the measurements near the top of the Maassluis Formation provide Strontium isotope ratios that are much too high. This has lead to the two-step trend in the measurements, as shown in Fig. 3. The value at $353.20 \mathrm{~m}$ is even outside the range of Beets' (1992) values for the 0 to $2.34 \mathrm{Ma}$ age interval. The lower samples $(383.7 \mathrm{~m}$, $403.7 \mathrm{~m}$ and $427.3 \mathrm{~m}$ ) suggest an age range between $0.82 \mathrm{Ma}$ and $1.15 \mathrm{Ma}$ for these sediments, which is in the Waalian to Menapian range (Fig. 7).

Herngreen (1997) correlated the dinoflagellate events in the interval from 355 to $435 \mathrm{~m}$ to the Tiglian A-C4b pollen zone ( 2 to $2.2 \mathrm{Ma}$ ) and from 467 to $552 \mathrm{~m}$ to the Praetiglian interval (2.2 to 2.5 $\mathrm{Ma}$ ). Since he based his subdivision on well-dated dinoflagellate events, the Strontium isotope ratio values seem to be too young by at least 0.7 to $1.0 \mathrm{Ma}$.

These higher Strontium ratios in the samples may point to diagenesis in the shell material. Although river influence of the Baltic rivers could have contributed to the higher Sr-isotope ratios, unrealistically low salinities for the seawater would have to be assumed in order for binary mixing of river- and seawater to completely account for the deviating Sr-isotope ratios. Diagenesis of this type can occur through in- 


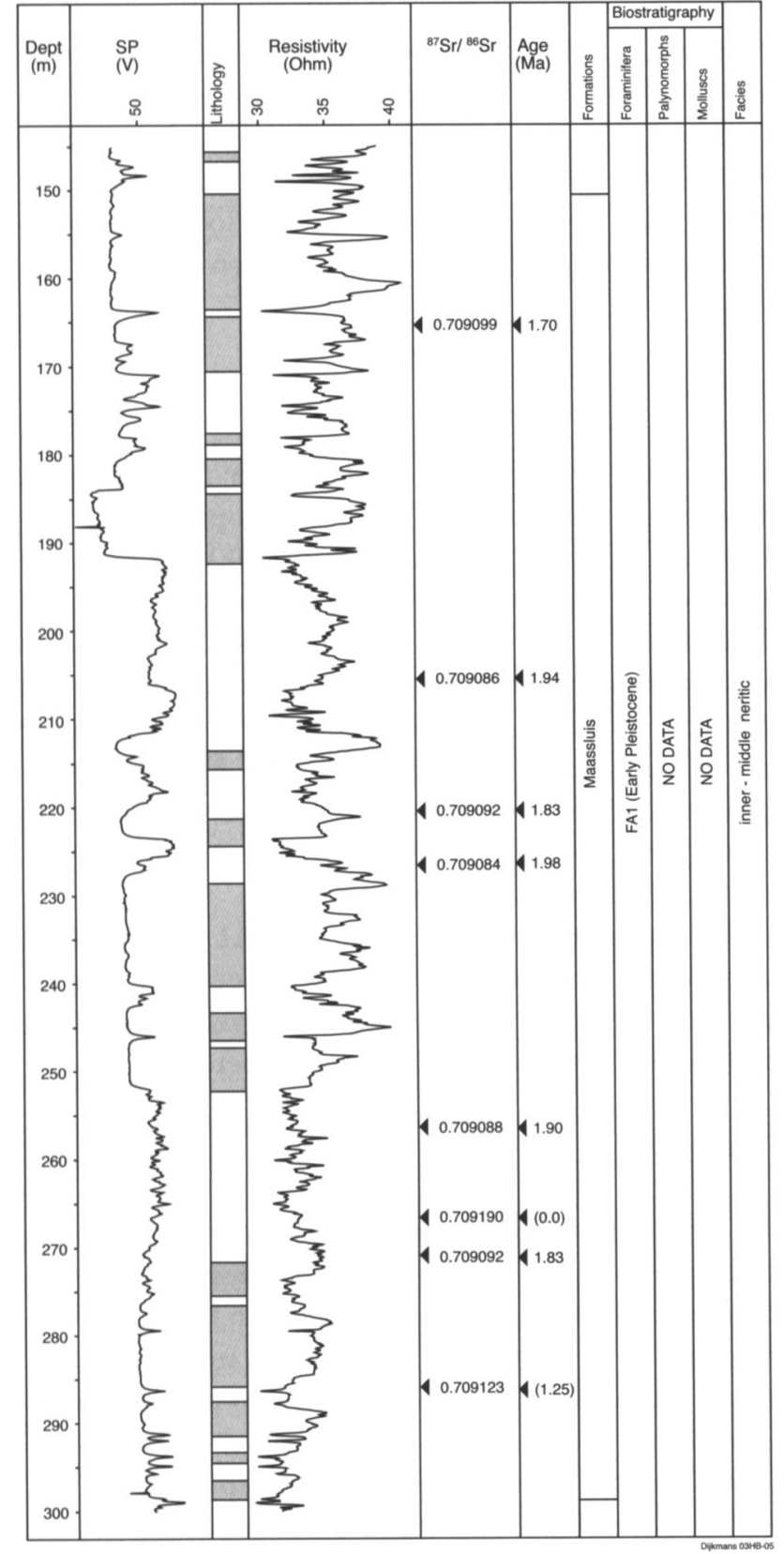

Fig. 5. Summary of the Zegveld borehole data. See Fig. 4 for explanation of lithology column.

troduction of fresh water down into older sediments under non-marine conditions.

\section{Conclusions}

The ages obtained from the Strontium ratios of the Maassluis Formation in Noordwijk (RD X: 91520, Y: 471800) and Zegveld (X: 115382, Y: 460157) are consistent with the age estimates previously given for the formation on other locations (Van Montfrans, 1971). Most ages lie within the Tiglian and Praetiglian intervals, the expected range.

The Sr-isotope age estimates for the base Maassluis
Formation and Oosterhout Formation in borehole Noordwijk indicate that these sediments are considerably older than earlier estimates based on biostratigraphic and environmental interpretations. The study of more locations will establish whether or not this is due to a local diagenetic effect.

At the Terschelling location, Sr-age estimates are consistently too young, which suggests diagenesis of the material and possibly introduction of high ${ }^{87} \mathrm{Sr} /{ }^{86} \mathrm{Sr}$ into the system by the Baltic rivers.

The age discrepancies at the Terschelling and Noordwijk locations highlight the need to rigorously test for diagenetic changes in shell material with various methods in addition to visual inspection.

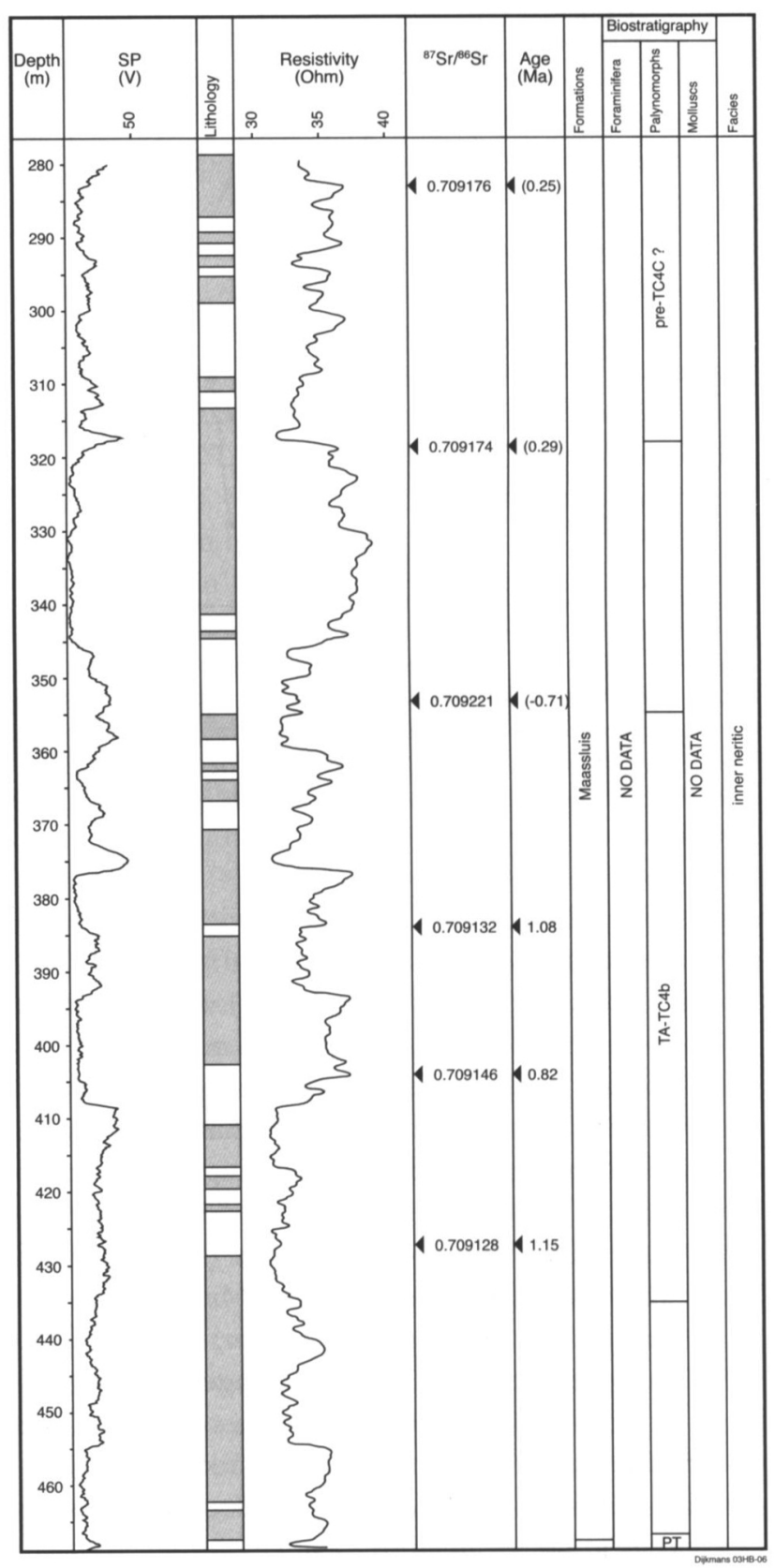

Fig. 6. Summary of the Terschelling borehole data. See Fig. 4 for explanation of lithology column. 


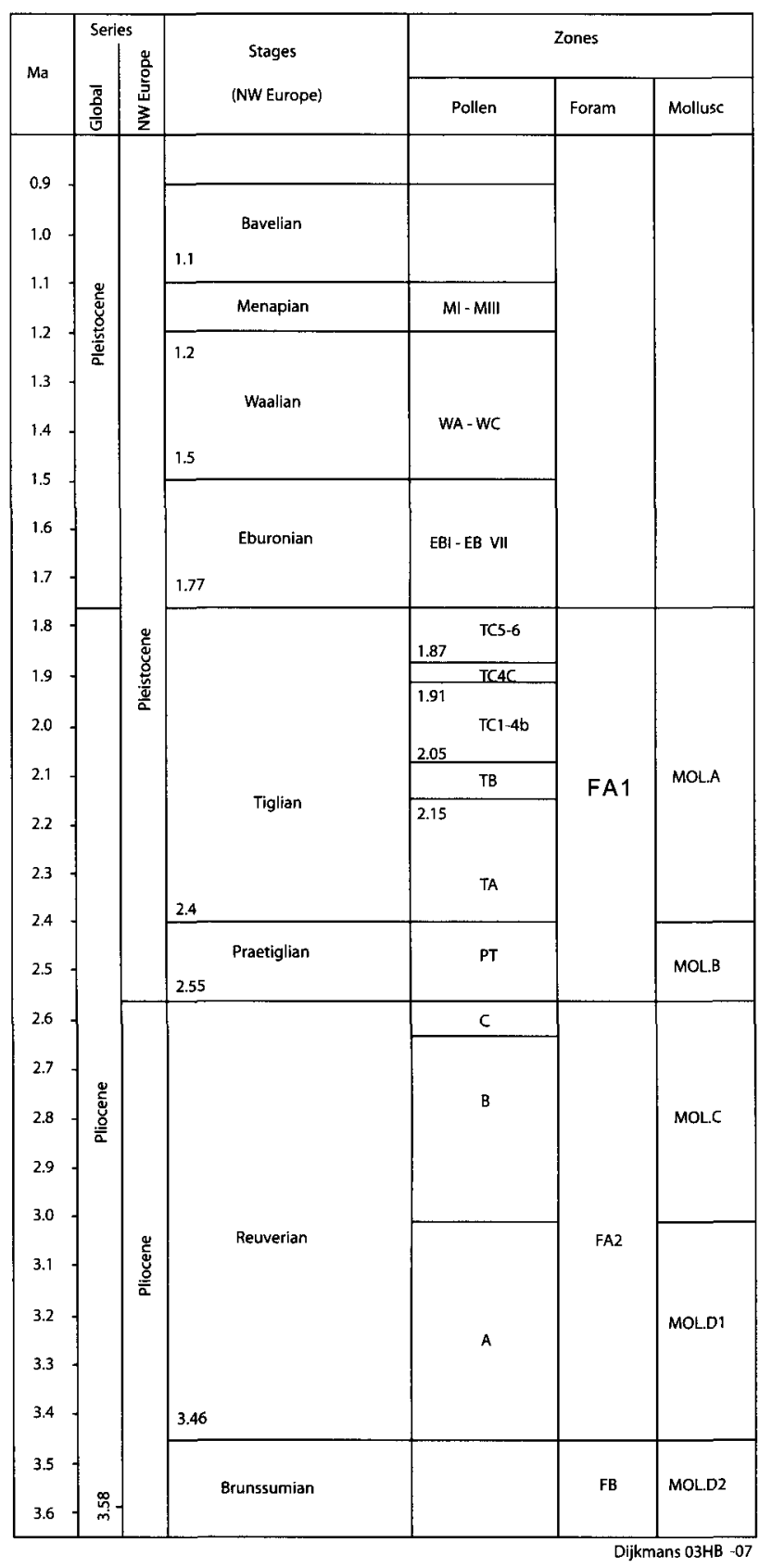

Fig. 7. Chronostratigraphy of the Pliocene/Pleistocene in The Netherlands (stages and zones after Zagwijn, 1975)

Strontium isotope ratios in the Pliocene and Lower Pleistocene shallow marine deposits of the Dutch onshore appear to be influenced by river discharge, and chronostratigraphy using these ratios should be undertaken with some trepidation in this type of sediments. As the discharge influence can be expected to lessen away from the coast it is advisable to extend the geographical spread of locations with Strontium isotope measurements on Massluis Formation sediments (or equivalents) to the offshore Netherlands area.

\section{References}

Beets, C.J., 1992. Calibration of late Cenozoic marine strontium isotope variations and its chronostratigraphic and geochemical applications. Drukkerij FEBO (Enschede): 133 pp.

Berggren, W.A., Kent, D.V., Flynn, J.J. \& Van Couvering, J.A., 1985. Cenozoic geochronology. Geological Society of America Bulletin 96: 1407-1418.

Berggren, W.A., Kent, D.V., Aubry, M.-P. \& Hardenbol, J. (Eds), 1995. Geochronology, time scales and global stratigraphic correlation. SEPM (Tulsa): 386 pp.

Burger, A.W., 1998. Sediment petrologisch onderzoek aan een diepe boring bij Noordwijk. TNO rapport NITG-98-257-C: 1-5.

Doppert, J.W.Chr., 1975. Foraminiferenzonering van het Nederlandse Onder-Kwartair en Tertiair. In: Zagwijn, W.H. \& Van Staalduinen, C.J. (Eds): Toelichting bij geologische overzichtskaarten van Nederland. Rijks Geologische Dienst (Haarlem): 114-118.

Doppert, J.W.Chr., Ruegg, G.H.J., Van Staalduinen, C.J., Zagwijn, W.H. \& Zandstra, J.G., 1975. Formaties van het Kwartair en Boven-Tertiair in Nederland. In: Zagwijn, W.H. \& Van Staalduinen, C.J. (Eds): Toelichting bij geologische overzichtskaarten van Nederland. Rijks Geologische Dienst (Haarlem): 114-118.

Farrel, J.W., Clemens, S.C. \& Gromet, L.P., 1995. Improved chronostratigraphical reference curve of late Neogene seawater ${ }^{87} \mathrm{Sr} /{ }^{86} \mathrm{Sr}$. Geology 23: 403-406.

Gibbard, P.L., West, R.G., Zagwijn, H.W., Balson, P.S., Burger, A.W., Funnell, B.M., Jeffery, D.H., De Jong, J., Van Kolfschoten, T., Lister, A.M., Meijer, T., Norton, P.E.P., Preece, R.C., Rose, J., Stuart, A.J., Whiteman, C.A. \& Zalasiewicz, J.A., 1991. Early and Early Middle Pleistocene correlations in the southern North Sea Basin. Quaternary Science Reviews 10: 23-52.

Herngreen, G.F.W., 1997. Dinoflagellaten onderzoek aan boring West Terschelling 05A/84. TNO rapport NITG-97-45-B: 1-7.

Howarth, R.J. \& McArthur, J.M., 1997. Statistics for strontium isotope stratigraphy: a robust LOWESS fit to the marine strontium isotope curve for the period 0 to $206 \mathrm{Ma}$, with look-up table for the derivation of numerical age. Journal of Geology 105: 441456.

Kasse, C., 1988. Early Pleistocene tidal and fluviatile environments in the southern Netherlands and northern Belgium. Free University Press (Amsterdam): 190 pp.

Kennett, J.P., 1982. Marine Geology. Prentice-Hall (englewood Cliffs): $752 \mathrm{pp}$.

Laban, C., 1995. The Pleistocene glaciations in the Dutch sector of the North Sea. Thesis University of Amsterdam (Amsterdam): 194 pp.

McArthur, J.M., Howarth, R.J. \& Baily, T.R., 2001. Strontium isotope stratigraphy: LOWESS version 3: Best fit to the marine $\mathrm{Sr}$ isotope curve for 0 - $509 \mathrm{Ma}$ and accompanying look-up table for deriving numerical age. Journal of Geology 109: 155-170.

Munsterman, D.K., 1999. De resultaten van het dinoflagellatenonderzoek aan boring 30F470 (Noordwijk), traject: 131.25 454.10m. TNO rapport NITG-99-108-B: 1-8.

Shackleton, N.J., Crowhurst, S., Hagelberg, T., Pisias, N.G. \& Schneider, D.A., 1995. A new late Neogene time scale and application to Leg 138 sites. In: Psisias, N.G., Mayer, L.A., Janecek, T.R., Palmer-Julsen, A. \& Van Andel, T.H. (eds.): Proceedings Ocean Drilling program Scientific Results 138: 73-101.

Van Kolfschoten, T. \& De Boer, P.L. (eds), 1988. The Zuurland-2 borehole. Mededelingen van de Werkgroep voor Tertiaire en Kwartaire Geologie 25: 1-106.

Van Leeuwen, R.J.W., 1999. Foraminiferenonderzoek aan de boring Noordwijk 30F470. TNO rapport NITG-99-145-B: 1-8.

Van Leeuwen, R.J.W., 2000. Foraminiferenonderzoek aan boring Zegveld 31D/160. TNO rapport NITG-00-62-B: 1-4.

Van Montfrans, H.M., 1971. Paleomagnetic dating in the North 
Sea Basin. Earth and Planetary Science Letters 11:226-236.

Van Montfrans, H.M., 1975. Toelichting bij de ondiepe breukenkaart met diepteligging van de Formatie van Maassluis. In: Zagwijn, W.H. \& Van Staalduinen, C.J. (Eds): Toelichting bij geologische overzichtskaarten van Nederland. Rijks Geologische Dienst (Haarlem) 103-108.

Vonhof, H.B., 1998. The strontium isotope stratigraphic record of selected geologic events. Ph.D. Thesis (Amsterdam): $138 \mathrm{pp}$.

Zagwijn, W.H., 1975. Indeling van het Kwartair op grond van veranderingen in vegetatie en klimaat. In: Zagwijn, W.H. \& Van Staalduinen, C.J. (Eds): Toelichting bij geologische overzichtskaarten van Nederland. Rijks Geologische Dienst (Haarlem): 109-114.

Zagwijn, W.H., 1998. Borders and boundaries: a century of stratigraphical research in the Tegelen-Reuver area of Limburg (The Netherlands). Mededelingen Nederlands Instituut voor Toegepaste Geowetenschappen TNO 60: 19-34.

Zagwijn, W.H. \& Van Staalduinen, C.J. (Eds), 1975. Toelichting bij geologische overzichtskaarten van Nederland. Rijks Geologische Dienst (Haarlem): $134 \mathrm{pp}$. 